\title{
Validasi Metode Analisis Tetrasiklin pada Ikan Nila (Oreochromis sp.) menggunakan Alat Kromatografi Cair Kinerja Tinggi (KCKT)
}

\section{Validation of Tetracycline Analysis Method on Tilapia Fish (Oreochromis Sp.) using High Performance Liquid Chromatography (HPLC)}

\author{
Nisa Hakimah ${ }^{*}$, R. Gagak Donny Satria $\uparrow^{2}$, Wari Pawestri ${ }^{3}$, \\ Soedarmanto Indarjulianto ${ }^{4}$ \\ ${ }^{1}$ Progran Studi Teknik Penanganan Patologi Perikanan, Politeknik Kelautan dan Perikanan Sidoarjo, \\ Jl. Raya Buncitan, Gedangan, Dusun Kp. Baru, Buncitan, Sidoarjo, Jawa Timur 61254 \\ ${ }^{2}$ Departemen Farmakologi, Fakultas Kedokteran Hewan, Universitas Gadjah Mada, \\ Jl. Fauna 2 Karangmalang, Depok, Sleman, Yogyakarta 55281 \\ ${ }^{3}$ Program Studi Peternakan, Fakultas Pertanian, Universitas Sebelas Maret, \\ Jl. Ir Sutami No.36 A, Pucangsawit, Jebres, Surakarta, Jawa Tengah 57126 \\ ${ }^{4}$ Departemen Ilmu Penyakit Dalam, Fakultas Kedokteran Hewan, Universitas Gadjah Mada, \\ Jl. Fauna 2 Karangmalang, Depok, Sleman, Yogyakarta 55281 \\ *Email: nisahakimah9293@gmail.com
}

Naskah diterima: 31 Maret 2018, direvisi: 06 Mei 2019, disetujui: 30 November 2019

\begin{abstract}
Antibiotics are substances that capable of inhibiting the growth of or killing microorganisms. The presence of residues in the tissues are associated with continuous use of antibiotics for long periods of time. The antibiotic residue that is often detected in freshwater fishery products is tetracycline. One method of analysis of tetracycline residues in fish meat is widely developed using high performance liquid chromatography (HPLC). This research was aimed to validate the method of analysis of tetracycline content in tilapia meat by using HPLC Shimadzu 6.1. The mobile phase consisting of methanol: acetonitrile: oxalic acid (5:15:80) with $1 \mathrm{ml} / \mathrm{min}$ flow rate, detector UV Vis with wavelength $355 \mathrm{~nm}$, and $\mathrm{C}_{18}$ Shim-pack column size $150 \mathrm{~L} \mathrm{x} \mathrm{4,6} \mathrm{mm} \mathrm{at} \mathrm{temperature} \mathrm{of} 30^{\circ} \mathrm{C}$. The result of this research showed values corresponding to validation criteria based on parameters of specificity, precision, accuracy, linearity, limit of detection, and limit of quantification. Tetracycline analysis using HPLC tool has good and acurate validity as the first step in detecting the tetracycline level in tilapia meat.
\end{abstract}

Key words: HPLC; tetracycline; tilapia fish; validation

\begin{abstract}
Abstrak
Antibiotik merupakan zat yang mampu menghambat pertumbuhan atau membunuh suatu mikroorganisme. Keberadaan residu di jaringan berhubungan dengan penggunaan antibiotik secara terus-menerus dalam jangka waktu lama. Residu antibiotik yang sering terdeteksi pada produk perikanan air tawar adalah tetrasiklin. Salah satu metode analisis terhadap kadar residu tetrasiklin pada daging ikan yang banyak dikembangkan secara luas yaitu menggunakan alat kromatografi cair kinerja tinggi (KCKT). Penelitian ini bertujuan untuk melakukan validasi metode analisis kadar tetrasiklin pada daging ikan nila dengan menggunakan alat KCKT merek Shimadzu 6.1. Fase gerak yang terdiri dari campuran metanol:asetonitril:asam oksalat (5:15:80) dengan laju alir $1 \mathrm{ml} / \mathrm{menit}$, detektor UV Vis dengan panjang gelombang $355 \mathrm{~nm}$, dan kolom $\mathrm{C}_{18}$ Shim-pack ukuran $150 \mathrm{~L}$ x 4,6 mm pada suhu $30^{\circ} \mathrm{C}$. Hasil penelitian menunjukkan nilai yang sesuai dengan kriteria validasi berdasarkan parameter spesifisitas, presisi, akurasi, linearitas, batas deteksi, dan batas kuantifikasi. Analisis tetrasiklin menggunakan alat KCKT menghasilkan validitas yang baik dan akurat sebagai langkah awal dalam mendeteksi kadar tetrasiklin pada daging ikan nila.
\end{abstract}

Kata kunci: ikan nila; KCKT; tetrasiklin; validasi 


\section{Pendahuluan}

Indonesia merupakan negara terbesar kedua di dunia sebagai produsen budi daya perikanan. Persentase peningkatan usaha budi daya perikanan dari tahun 2000 sebesar 21\% setiap tahun (Saputri, 2017). Ikan nila merupakan salah satu komoditas penting dalam budi daya perikanan air tawar di Indonesia karena mudah dipelihara, bersifat eurihaline, laju pertumbuhan dan perkembangbiakannya cepat, serta tahan terhadap gangguan hama dan penyakit (Ardita dkk., 2015 dan Djunaedi dkk., 2016). Ikan nila sangat diminati oleh pasar dalam negeri dan pasar luar negeri. Ekspor fillet nila dalam bentuk beku dari Indonesia ke Amerika pada tahun 2004 mencapai 4.250 ton dan menduduki peringkat kedua setelah Cina. Permintaan yang cenderung meningkat menyebabkan budi daya ikan nila di Indonesia semakin meningkat dari tahun ke tahun. Permintaan pasar dunia terhadap ekspor fillet nila dari Indonesia hanya mampu melayani tidak lebih dari 0,1\% (Wijaya dkk., 2015).

Jumlah ekspor produk perikanan dari Indonesia yang tidak mampu mencukupi permintaan pasar dunia diakibatkan oleh beberapa kasus penolakan. Salah satu kasus penolakan ekspor produk perikanan yang menjadi perhatian dunia adalah keberadaan residu kimia dalam jaringan. Keberadaan residu di jaringan dalam budi daya perikanan yang sering terjadi berhubungan dengan penggunaan antibiotik secara terus-menerus dalam jangka waktu lama (Lukistyowati dan Syawal, 2013 dan Nurhasnawati dkk., 2016). United States Center for Disease Control and Prevention dalam penelitian yang dilakukan oleh Lekshmi dkk. (2017) menyatakan bahwa antibiotik telah digunakan dalam dunia perikanan untuk growth promotor, efisiensi pakan, serta pencegahan dan pengobatan infeksi penyakit. Berdasarkan penelitian yang dilakukan oleh Mahmoudi dkk. (2014), Nurhasnawati dkk. (2016), serta Turk dan Halis (2016) menyatakan bahwa residu antibiotik yang sering terdeteksi pada ikan adalah tetrasiklin. Residu adalah sisa dari bahan kimia atau metabolitnya dalam jaringan atau organ hewan (Rahayu, 2009). Kadar residu antibiotik tetrasiklin dalam daging ikan yang direkomendasikan oleh Badan Standardisasi Nasional (2000) dan Vishnuraj dkk. (2016) adalah 0,1 ppm.

Salah satu metode analisis terhadap kadar residu antibiotik yang banyak dikembangkan secara luas adalah alat kromatografi cair kinerja tinggi (KCKT) (Anastasia, 2011). Metode analisis dengan alat KCKT memiliki beberapa kelebihan yaitu waktu analisis cepat, jumlah sampel yang diperlukan sedikit, kepekaan tinggi, dapat digunakan pada sampel organik atau anorganik, memiliki daya pisah molekul yang baik, dapat menggunakan berbagai macam detektor, dan kolom yang telah digunakan dapat digunakan kembali (Sabrina dkk., 2012).

Penelitian ini bertujuan untuk melakukan validasi metode analisis kadar tetrasiklin dengan menggunakan alat KCKT sebagai langkah awal dalam mendeteksi kadar tetrasiklin pada daging ikan nila. Validasi metode analisis merupakan suatu penilaian terhadap parameter tertentu berdasarkan percobaan laboratorium untuk membuktikan bahwa parameter tersebut memenuhi persyaratan untuk penggunaannya (Harmita, 2004). Parameter dalam melakukan validasi metode analisis adalah linearitas, spesifisitas, presisi, akurasi, batas deteksi, dan batas kuantifikasi (Sugihartini dkk., 2014). Penelitian ini diharapkan memberikan informasi yang akurat mengenai metode analisis tetrasiklin pada daging ikan nila menggunakan KCKT dan dapat dijadikan sebagai pedoman penelitian yang akan datang.

\section{Materi dan Metode}

Antibiotik yang digunakan dalam penelitian ini adalah tetracycline hydrochloride 95\% (SigmaAldrich) dengan dosis bertingkat mulai $2,5 \mu \mathrm{g} / \mathrm{ml} ; 5$ $\mu \mathrm{g} / \mathrm{ml} ; 7,5 \mu \mathrm{g} / \mathrm{ml} ; 10 \mu \mathrm{g} / \mathrm{ml} ; 12,5 \mu \mathrm{g} / \mathrm{ml}$; dan $15 \mu \mathrm{g} / \mathrm{ml}$. Daging ikan nila (Oreochromis sp.), metanol 99,9\%, asetonitril $99,9 \%$, asam oksalat dihidrat $0,126 \%$, di-sodium hydrogen phosphate $\left(\mathrm{Na}_{2} \mathrm{HPO}_{4}\right)$, citric acid monohydrate $\left(\mathrm{C}_{6} \mathrm{H}_{8} \mathrm{O}_{7}-\mathrm{H}_{2} \mathrm{O}\right)$, ethylene dinitrilo tetraacetic acid ( $\left.\mathrm{Na}_{2} \mathrm{EDTA}\right)$, aqua bidestilata, dan aquades juga digunakan dalam penelitian ini.

Alat yang digunakan berupa alat KCKT Shimadzu 6.1 dengan sistem kontrol SCL-10A VP, detektor SPD10AV VP, degasser DGU-14A, pompa LC-10AD VP, oven CTO-10AC VP, dan kolom $\mathrm{C}_{18}$ Shim-pack (150 $\mathrm{L} \times 4,6 \mathrm{~mm}$ ). Alat lain yang digunakan adalah syringe KCKT, ultrasonic bath, mikropipet, tip mikropipet, microtube $2 \mathrm{ml}$, vortex mixer, centrifuge, timbangan digital, spatula, gelas ukur, gelas beker, batang pengaduk, kertas perkamen, kertas saring, tabung konikel, labu erlenmeyer, labu ukur, pisau, dan telenan.

Penelitian ini dilakukan di Laboratorium Farmakologi, Fakultas Kedokteran Hewan, Universitas Gadjah Mada. Metode yang digunakan merupakan pengembangan metode berdasarkan Badan Standardisasi Nasional (2009), Balta dan Hasmet (2010), Olatoye dan Afisu (2013), Mahmoudi dkk. (2014), 
Nurhasnawati dkk. (2016), Turk dan Halis (2016), serta Wijayanti dkk. (2010). Tahapan dalam penelitian ini adalah pembuatan Bufer McIlvaine, pembuatan larutan standar, preparasi sampel, injeksi sampel, dan analisis hasil.

Bufer McIlvaine digunakan sebagai pelarut larutan standar dan preparasi jaringan ikan nila. Bufer McIlvaine merupakan campuran dari $\mathrm{Na}_{2} \mathrm{HPO}_{4}$, $\mathrm{C}_{6} \mathrm{H}_{8} \mathrm{O}_{7}-\mathrm{H}_{2} \mathrm{O}$, dan $\mathrm{Na}_{2}$ EDTA dalam aquabidestilata. Sebanyak 23,41 gram $\mathrm{Na}_{2} \mathrm{HPO}_{4}$ dan 21,01 gram $\mathrm{C}_{6} \mathrm{H}_{8} \mathrm{O}_{7}-\mathrm{H}_{2} \mathrm{O}$ masing-masing dilarutkan dalam 1 liter aqua bidestilata. Larutan $\mathrm{Na}_{2} \mathrm{HPO}_{4}$ sebanyak $625 \mathrm{ml}$ dicampurkan dengan 1 liter larutan $\mathrm{C}_{6} \mathrm{H}_{8} \mathrm{O}_{7}-\mathrm{H}_{2} \mathrm{O}$ ke dalam labu ukur yang selanjutnya ditambah dengan $\mathrm{Na}_{2}$ EDTA sebanyak 60,49 gram. Larutan yang sudah tercampur secara homogen dimasukkan ke dalam tabung erlenmeyer yang kemudian dimasukkan ke dalam ultrasonic bath yang telah terisi aquades dengan suhu $30{ }^{\circ} \mathrm{C}$ selama 15 menit.

Larutan standar dibuat dengan melarutkan 10 mg tetrasiklin murni dengan metanol sebanyak 10 $\mathrm{ml}$. Pengenceran larutan standar dilakukan dengan menggunakan pelarut Bufer Mcllvaine. Dosis bertingkat yang digunakan adalah $2,5 \mu \mathrm{g} / \mathrm{ml} ; 5 \mu \mathrm{g} / \mathrm{ml}$; $7,5 \mu \mathrm{g} / \mathrm{ml} ; 10 \mu \mathrm{g} / \mathrm{ml} ; 12,5 \mu \mathrm{g} / \mathrm{ml}$; dan $15 \mu \mathrm{g} / \mathrm{ml}$ yang selanjutnya akan ditambahkan pada daging ikan nila.

Sebanyak 1 gram daging ikan nila yang telah dihaluskan, dimasukkan ke dalam tabung konikel pertama dan ditambahkan Bufer McIlvaine sebanyak $5 \mathrm{ml}$ yang kemudian dihomogenkan dengan menggunakan vortex mixer selama 30 detik. Bufer McIlvaine sebanyak $4 \mathrm{ml}$ ditambahkan lagi ke dalam konikel pertama yang kemudian dihomogenkan dengan langkah yang sama dan disentrifugasi selama 10 menit dengan kecepatan $2500 \mathrm{~g}$. Supernatan diambil, disaring, dan ditampung pada tabung konikel kedua. Tabung konikel pertama ditambahkan $4 \mathrm{ml}$ Bufer Mcllvaine, dihomogenkan, dan disentrifugasi dengan langkah yang sama. Supernatan diambil dan ditambahkan pada tabung kedua. Sisa homogenat tabung pertama dibilas kembali dengan menggunakan $2 \mathrm{ml}$ Bufer Mcllvaine, dihomogenkan, dan disentrifugasi dengan langkah yang sama. Supernatan ditambahkan kembali pada tabung kedua yang selanjutnya supernatan kolektif pada tabung kedua disentrifugasi selama 20 menit dengan kecepatan $2500 \mathrm{~g}$ dan disaring ke tabung ketiga serta diberi label.

Analisis tetrasiklin menggunakan alat KCKT tipe isokratik (Shimadzu versi 6.1). Fase gerak yang digunakan merupakan campuran dari metanol, asetonitril, dan asam oksalat dalam akuabides $(5: 15: 80)$ yang dialirkan pada laju alir $1 \mathrm{ml} / \mathrm{menit}$. Kolom yang digunakan yaitu $\mathrm{C}_{18}$ Shim-pack dengan ukuran 150 L x 4,6 mm dan detektor UV-Vis yang dioperasikan pada panjang gelombang $355 \mathrm{~nm}$ dalam suhu $30{ }^{\circ} \mathrm{C}$. Optimasi alat KCKT dioperasikan pada running time 7 menit. Sampel diinjeksikan menggunakan syringe khusus KCKT dengan ukuran $20 \mu 1$. Detektor mampu mendeteksi kandungan tetrasiklin dalam sampel dan menghasilkan kromatogram. Parameter validasi yang dianalisis dari hasil penelitian meliputi spesifisitas, presisi, tingkat akurasi, linearitas, batas kuantifikasi, dan batas deteksi.

\section{Hasil dan Pembahasan}

Sampel daging ikan nila yang telah ditambahkan tetrasiklin pada berbagai konsentrasi yang telah ditentukan dianalisis dengan menggunakan alat Kromatografi Cair Kinerja Tinggi (KCKT). Validasi metode dilakukan dengan beberapa parameter yaitu spesifisitas, presisi, tingkat akurasi, linearitas, batas kuantifikasi, dan batas deteksi (Rohman, 2009).

\section{Spesifisitas}

Spesifisitas merupakan kemampuan suatu metode analisis dalam mengukur analit yang dituju secara tepat dan spesifik dengan adanya komponen-komponen lain yang terdapat dalam matriks sampel. Spesifisitas diukur dengan membandingkan hasil analisis sampel yang mengandung bahan tambahan atau cemaran dengan hasil analisis sampel tanpa bahan tambahan (Rohman, 2009). Hasil kromatogram sampel blangko dan kromatogram sampel yang telah ditambahkan tetrasiklin ditunjukkan pada gambar 1 dan gambar 2.

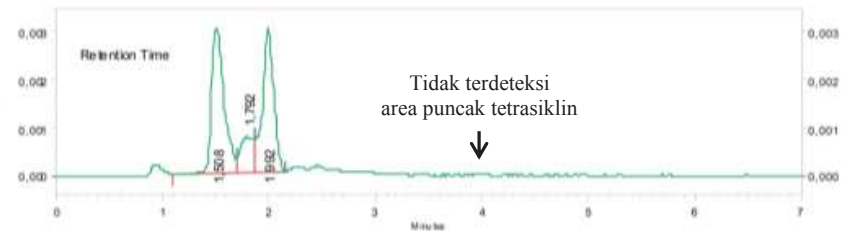

Gambar 1. Hasil kromatogram sampel blangko

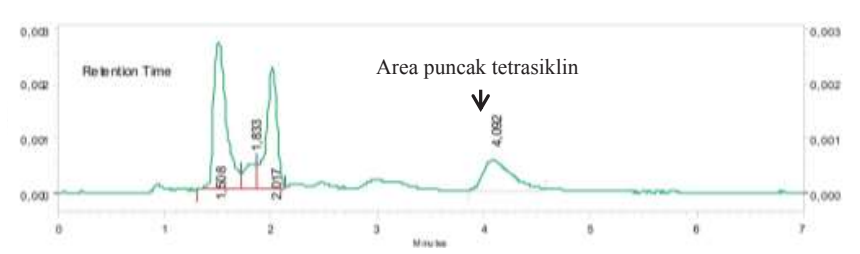

Gambar 2. Hasil kromatogram spiking tetrasiklin pada daging ikan nila dengan dosis $1,5 \mu \mathrm{g} / \mathrm{g}$ 
Tabel 1. Data perhitungan hasil kromatogram sampel yang ditambahkan tetrasiklin dengan enam konsentrasi bertingkat.

\begin{tabular}{cccc}
\hline $\begin{array}{c}\text { Konsentrasi } \\
(\mu \mathrm{g} / \mathrm{g})\end{array}$ & $\begin{array}{c}\text { Rata-rata luas } \\
\text { area puncak }\end{array}$ & RSD (\%) & Akurasi (\%) \\
\hline 1,5 & 10543,3 & 0,03 & 101 \\
1,25 & 8624 & 0,02 & 100 \\
1 & 6201,33 & 0,03 & 91 \\
0,75 & 5377 & 0,06 & 107 \\
0,5 & 3615,33 & 0,08 & 110 \\
0,25 & 1189,33 & 0,08 & 85 \\
\hline
\end{tabular}

Berdasarkan hasil kromatogram, gambar 1 dan gambar 2 menunjukkan perbedaan analisis hasil kromatogram antara sampel blangko dengan sampel spiking tetrasiklin pada daging ikan nila. Berdasarkan hasil kromatogram gambar 1, tidak menunjukkan area puncak dengan waktu retensi antara menit ke- 4,0 sampai menit ke-4,2 sedangkan gambar 2 menunjukkan kemunculan area puncak pada menit ke-4,092. Kemunculan area puncak pada gambar 2 menunjukkan bahwa metode analisis kromatografi cair kinerja tinggi (KCKT) dapat mendeteksi keberadaan tetrasiklin.

Rata - rata luas area yang terbentuk pada Tabel 1 menunjukkan bahwa semakin tinggi konsentrasi tetrasiklin yang ditambahkan maka semakin besar luas area puncak yang terbentuk. Luas area puncak yang terbentuk pada setiap kronsentrasi tetrasiklin yang ditambahkan pada sampel juga dapat diamati sebagai penentuan parameter spesifisitas. Berdasarkan hasil kromatogram yang terbentuk menunjukkan bahwa metode analisis dengan alat KCKT dapat membedakan senyawa tetrasiklin secara cermat dan tepat pada waktu retensi tertentu dengan tidak terdeteksi kemunculan senyawa pengganggu pada area puncak tersebut sehingga parameter spesifisitas dapat dikategorikan baik.

\section{Presisi}

Presisi merupakan suatu ukuran kedekatan pada serangkaian hasil analisis dengan beberapa kali pengukuran pada sampel homogen (Rohman, 2009). Presisi dibagi menjadi tiga parameter yaitu keterulangan (repeatability), presisi antara (intermediate precision), dan ketertiruan (reproducibility) (Chan, 2008). Keterulangan merupakan ketepatan pada kondisi percobaan yang sama baik orang, peralatan, tempat, maupun waktu. Keterulangan dapat diukur dengan pengulangan minimal enam kali dengan konsentrasi analit $100 \%$ atau dapat pula dilakukan dengan pengulangan minimal sembilan kali yaitu tiga konsentrasi dengan tiga kali pengulangan (Rohman, 2009). Berdasarkan Tabel 1 menunjukkan data perhitungan hasil kromatogram sampel yang ditambahkan tetrasiklin dengan konsentrasi bertingkat. Tingkat keterulangan dalam penelitian ini ditunjukkan oleh enam sampel dengan pengulangan masing-masing sebanyak tiga kali.

Kriteria presisi yang baik diberikan jika metode menunjukkan nilai relative standart deviation (RSD) atau koefisien variasi sebesar $2 \%$ atau kurang (Harmita, 2004). Nilai RSD yang disajikan Tabel 1 yaitu antara nilai $0,02-0,08 \%$. Nilai RSD yang dihasilkan memiliki nilai kurang dari $2 \%$. Hal tersebut menunjukkan bahwa metode analisis memiliki nilai presisi yang baik karena dapat mendeteksi tetrasiklin dengan nilai luas area yang tetap pada konsentrasi tertentu.

\section{Tingkat akurasi}

Akurasi merupakan parameter ukuran yang ditunjukkan dengan derajat kedekatan hasil analisis dengan kadar analit yang sebenarnya dan dinyatakan sebagai persen perolehan kembali (recovery) analit yang ditambahkan (Harmita, 2004). Penentuan akurasi dilakukan dengan metode analisis terhadap senyawa tersebut dan menganalisisnya secara kuantitatif dengan membandingkan hasil analisis antara senyawa standar dengan kemurnian yang sudah diketahui (Rohman, 2009).

Hasil perhitungan nilai recovery yang disajikan pada Tabel 1 diketahui bahwa nilai recovery antara 85$110 \%$. Hal tersebut menunjukkan bahwa nilai recovery pada penelitian ini sesuai dengan parameter dari FDA (2001) yaitu 80-120\%. Metode analisis dalam penelitian ini dapat dikatakan akurat karena memiliki tingkat kedekatan yang tinggi antara hasil analisis dengan kadar analit yang ditambahkan.

\section{Linearitas}

Linearitas merupakan kemampuan suatu metode uji dalam menghasilkan suatu hasil uji yang proporsional terhadap kepekatan analit sampel dalam jangkauan kepekatan yang ada (Harmita, 2004). Linearitas ditentukan dengan metode regresi kuadrat kecil sebanyak tiga kali pengulangan untuk setiap konsentrasi (Anastasia, 2011).

Pengukuran linearitas dilakukan dengan membuat pengenceran bertingkat sebanyak enam titik dosis. 


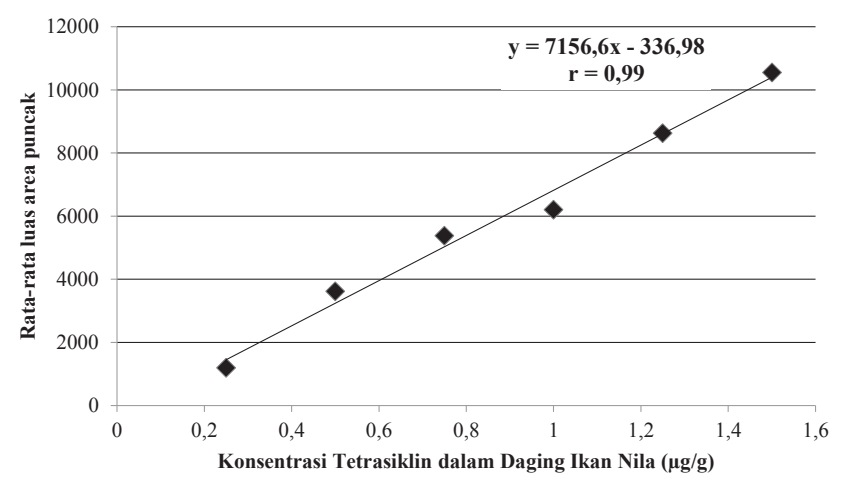

Gambar 3. Grafik linearitas sampel daging ikan nila yang ditambahkan tetrasiklin

Linearitas yang baik akan menunjukkan nilai $r \geq 0,99$ (AOAC, 2002). Berdasarkan hasil pengujian linearitas pada Gambar 3 diperoleh suatu persamaan linear $\mathrm{y}=$ $7156,6 x-336,98$ dengan nilai $r=0,99$. Nilai $r$ yang dihasilkan sesuai dengan yang direkomendasikan oleh AOAC (2002). Hal ini menunjukkan bahwa metode analisis yang digunakan memenuhi kriteria linearitas yang baik.

\section{Batas kuantifikasi}

Batas kuantifikasi adalah konsentrasi terendah suatu analit yang dapat dianalisis secara kuantitatif dan memenuhi persyaratan presisi yang diterima pada kondisi operasional metode analisis (Kazusaki dkk., 2012). Batas kuantifikasi sampel daging ikan nila yang telah ditambahkan tetrasiklin berdasarkan perhitungan rumus batas kuantifikasi adalah $0,68 \mu \mathrm{g} / \mathrm{g}$.

\section{Batas deteksi}

Batas deteksi dilakukan untuk mengetahui suatu analit dengan konsentrasi terendah dalam sampel yang dapat dideteksi dan memberikan respon signifikan dibandingkan dengan blangko (Harmita, 2004). Batas deteksi sampel daging ikan nila yang telah ditambahkan tetrasiklin berdasarkan perhitungan rumus batas deteksi adalah $0,2 \mu \mathrm{g} / \mathrm{g}$.

\section{Kesimpulan}

Metode analisis tetrasiklin pada daging ikan nila menggunakan alat KCKT memiliki validitas yang baik dan tepat pada waktu retensi tertentu. Metode analisis ini dapat digunakan sebagai langkah awal dalam mendeteksi kadar tetrasiklin pada daging ikan nila.

\section{Ucapan Terima Kasih}

Penelitian ini merupakan bagian dari rangkaian penelitian dan masih terus dikembangkan. Ucapan terima kasih kepada pihak Departemen Farmakologi, Fakultas Kedokteran Hewan UGM yang telah memberikan fasilitas dalam penelitian ini.

\section{Daftar Pustaka}

Anastasia, Y. (2011). Teknik Analisis Residu Tetrasiklin Golongan Tetrasiklin dalam Daging Ayam Secara Kromatografi Cair Kinerja Tinggi. Buletin Teknik Pertanian. 16 (2): 68-73.

Ardita, N., Agung B., dan Siti L. (2015). Pertumbuhan dan Rasio Konversi Pakan Ikan Nila (Oreochromis niloticus) dengan Penambahan Prebiotik. Jurnal Bioteknologi. 12 (1): 16-21.

Association of Official Analytical Chemists. (2002). AOAC International Methods Committee Guidelines for Validation of Qualitative and Quantitative Food Microbiological Official Methods of Analysis. The Journal of AOAC International. 85: 1-5.

Badan Standardisasi Nasional. (2000). Batas Maksimum Cemaran Mikroba dan Batas Maksimum Residu dalam Bahan Makanan Asal Hewan. SNI 01.6366.2000, Jakarta: 1-12.

Badan Standarisasi Nasional. (2009). Cara Uji Kimia - Bagian 11: Penentuan Residu Tetrasiklin dan Derivatnya dengan Kromatografi Cair Kinerja Tinggi (KCKT) Pada Produk Perikanan. SNI 2354, 11: 2009. Badan Standarisasi Nasional, Jakarta.

Balta, F. dan Hasmet C. (2010). Oxytetracycline Residues in Cultured Gilthead Sea Bream (Sparus aurata L. 1758) Tissues. Africa Journal Biotechnology. 9 (42): 7192-7196.

Chan, C. (2008). Analytical Method Validation Principles and Practices, Pharmaceutical Manufacturing Handbook: Regulation and Quality. Azopharma Contract Pharmaceutical Services: Florida: 16-22.

Djunaedi, A., Retno H., Rudhi P., Sri R., Retno W., dan Bintang S. 2016. Pertumbuhan Ikan Nila Larasati (Oreochromis niloticus) di Tambak dengan Pemberian Ransum Pakan dan Padat Penebaran yang Berbeda. Jurnal Kelautan Tropis. 19 (2): 131-142.

Food and Drug Administration. (2001). Guidance for industry: Bioanalytical method validation. 
Center for Drug Evaluation and Research, Rockville. USA: 6.

Harmita. (2004). Petunjuk Pelaksanaan Validasi Metode dan Cara Perhitungannya. Majalah Ilmu Kefarmasian. 1 (3): 117-135.

Kazusaki, M., Ueda, S., Takeuchi, N., Ohgami, Y. (2012). Validation of Analytical Procedures by High-Performance Liquid Chromatography for Pharmaceutical Analysis. Journal of Chromatography. 33 (2): 65-73.

Lekshmi, M., Parvathi A., Sanath K., dan Mannuel F. (2017). The Food Production Environment and the Development of Antimicrobial Resistance in Human Pathogens of Animal Origin. Journal of Microorganisms. 5 (11): 1-15.

Lukistyowati, I., dan Syawal, H. (2013). Potensi Pakan yang Mengandung Sambiloto (Andrographis paniculata) dan Daun Jambu Biji (Psidium guajava) untuk Menanggulangi Bakteri Aeromonas hydrophila pada Ikan Baung (Mystus nemurus). Jurnal Akuakultur Rawa Indonesia. 1 (2): 135-147.

Mahmoudi, R., P. Gasarbeygi, R. Norian, dan K. Farhoodi. (2014). Chloramphenicol, Sulfonamide, and Tetracycline Residues in Cultured Rainbow Trout Meat (Oncorhynchus mykiss). Bulgarian Journal of Veterinary Medicine. 17 (2): 147-152.

Nurhasnawati, H., Siti J., dan Novita E. (2016). Penentuan Kadar Residu Tetrasiklin $\mathrm{HCl}$ pada Ikan Air Tawar yang Beredar di Pasar Segiri Menggunakan Metode Spektrofotometri Ultra Violet. Jurnal Ilmiah Manuntung. 2 (2): 173178.

Olatoye, I. O. dan Basiru, A. (2013). Antibiotic Usage and Oxytetracycline Residu in African Catfish (Clarias gariepinus in Ibadan, Nigeria). World Journal of Fish and Marine Sciences. 5 (3): 302-309.

Rahayu, W. S., Dwi H., dan Agus M. (2009). Analisis Residu Pestisida Organoklorin pada Rimpang Kunyit (Curcuma domestica) secara M Spektrofotometri Ultraviolet Visibel. Journal of Pharmacy. 6 (1): 69-75.
Rohman, A. (2009). Kromatografi untuk Analisis Obat. Graha Ilmu. Yogyakarta: 110-119, 217-240.

Sabrina, A., Wonorahardjo, S., Zakia, N. (2012). Perbandingan Metode Spektofotometri UV-Vis dan KCKT (Kromatografi Cair Kinerja Tinggi) pada analisis Kadar Asam Benzoate dan Kafein Teh Kemasan. Jurnal Universitas Negeri Malang . 1 (1).

Saputri, K. (2017). Peluang dan Kendala Ekspor Udang Indonesia ke Pasar Jepang. Jurnal Ilmu Hubungan International. 5 (4): 1179-1194.

Sugihartini, N., Fudholi, A., Pramono, S., dan Sismindari. (2014). Validasi Metode Analisa Penetapan Kadar Epigalokatekin Galat dengan Kromatografi Cair Kinerja Tinggi. Jurnal Pharmaciana. 4 (2): 111-115.

Turk, E. dan Halis O. (2016). Investigation of Tetracycline Residues in Fish Caught from Surrounding Fish Farm in Mugla District. Eurasian Journal of Veterinary Sciences. 32 (2): 74-79.

Vishnuraj, M., G. Kandeepan, K. H. Rao, S. Chand, dan V. Kumbhar. (2016). Occurence, Public Health Hazards and Detection Methods of Antibiotic Residues in Food of Animal Origin: A Comprehensive Review. Journal of Cogent Food and Agriculture. 2: 1-8.

Wijayanti, A. D., Hakim, L., Widiyono, I., Irianti, T. (2010). Penentuan Efektifitas Oksitetrasiklin Melalui Parameter Farmakokinetiko/ Farmakodinamik pada Plasma dan Jaringan Ayam Broiler. Jurnal Veteriner. 11 (2): 119-125.

Wijaya, O. A., Titi S., dan Sumardianto. (2015). Pengaruh lama Perendaman $\mathrm{NaOH}$ Removal Proses Penghilangan Lemak Terhadap Kualitas Gelatin Tulang Ikan Tulang Nila. Jurnal Pengolahan dan Bioteknologi Hasil Perikanan. 4 (2): 25-32 